\title{
TEN NEW RECORDS OF SOUTH KOREAN MOSSES
} \author{
ДЕСЯТЬ НОВЫХ ТАКСОНОВ МХОВ ДЛЯ ЮЖНОЙ КОРЕИ

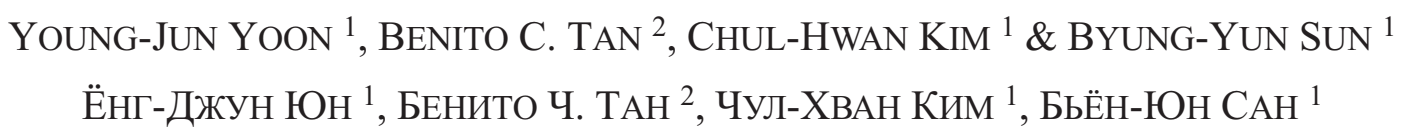

Abstract

Two moss varieties new to science, namely Fissidens involutus Wilson ex Mitt. var. jejuensis Y.-J. Yoon, B. C. Tan \& B.-Y. Sun, var. nov. and Leskeodon maibarae var. jejuensis Y.-J. Yoon, B. C. Tan \& B.-Y. Sun, var. nov., are described, and a total of eight new records of taxa of mosses of South Korea, which include Dicranum montanum, Fissidens anomalus, Fissidens crispulus var. robinsonii, Leskeodon maibare, Okamuraea hakoniensis fo. multiflagellifera, Pylaisia selwynii, Sematophyllum phoeniceum and Sematophyllum subpinnatum, are reported. Of these, seven are also new moss records for the entire Korean Peninsula, including North Korea. These noteworthy moss specimens were collected from various parts of South Korea, and the two new varieties are from Jeju-do (Jeju Island). The phytogeographical role of Jeju Island in the post-glacial migration and speciation of the cryptogamic flora of Korean Peninsula is briefly mentioned.

Резюме

Описаны две новых для науки разновидности, Fissidens involutus Wilson ex Mitt. var. jejuensis Y.-J. Yoon, B.C. Tan \& B.-Y. Sun, var. nov. и Leskeodon maibarae var. jejuensis Y.-J. Yoon, B.C. Tan $\&$ B.-Y. Sun, var. nov.; шесть видов, одна форма и одна разновидность приводятся впервые для Южной Кореи: Dicranum montanum, Fissidens anomalus, Fissidens crispulus var. robinsonii, Leskeodon maibare, Okamuraea hakoniensis fo. multiflagellifera, Pylaisia selwynii, Sematophyllum phoeniceum и Sematophyllum subpinnatum. Семь из этих таксонов являются новыми для всего Корейского полуострова, включая Северную Корею. Образцы этих таксонов были собраны в разных частях Южной Кореи, при этом две новые для науки разновидности найдены на Чеджудо (остров Чеджу). Кратко обсуждается фитогреографическое значение этого острова в расселении и видообразовании криптогамной флоры в послеледниковый период на Корейском полуострове.

KEYWORDS: Jeju-do, South Korea, Korean Peninsula, mosses, new species, Dicranum, Fissidens, Leskeodon, Okamuraea, Sematophyllum

\section{INTRODUCTION}

In its early history, the moss flora of the Korean Peninsula was studied mainly by western and Japanese scholars. The first western collector of mosses on the Korean Peninsula was Father Urbain Jean Faurie (1847-1915) from France and his collections were studied by Cardot (1904). From 1930 to 1940, several Japanese scholars, namely S. Okamura, Y. Horikawa, H. Sasaoka, A. Noguchi and T. Osada, collected and studied bryophytes from the Korean Peninsula (Song \& Yamada, 2001, 2003). Starting in the 1960 s, the study of the moss flora of Korea was undertaken by Korean bryologists (Hong, 1960a, 1960b; Hong \& Ando, 1961; Choe, 1962, 1972, 1977a, 1977b, 1978, 1979). As a result, The Illustrated Flora and Fauna of Korea, Vol. 24 (Musci, Hepaticae) prepared by Choe was published in 1980. This book contains 487 species belonging to 158 genera and 48 families. The species number corresponds to only about $4.8 \%$ of all the mosses then recognized in the world (cf. Schofield, 1985). In the past 30 years, more studies on Korean mosses have been performed jointly by local and foreign botanists who yielded new information about Korean moss biodiversity (Gao \& Chang, 1983a, 1983b; Kim et al., 1995; Lai et al., 2007; He \& Song, 2007; Yoon \& Sun, 2010; Yoon et al., 2011a, 2011b). In spite of these efforts, the moss flora of the Korean Peninsula remains insufficiently studied.

In as much as the moss floras of several countries and areas in East Asia, such as the Russian Far East, China, Taiwan and Japan, are now relatively well known, it has become more necessary today to study the less known moss flora of the Korean Peninsula in order to understand the evolution and relationship of the bryophyte floras of these countries in Northeast Asia.

While preparing a floristic study, the first author collected ten new moss records for the South Korean flora which are reported below in two groups and arranged in alphabetical order. Seven of these are also new species records for the entire Korean Peninsula.

Two of the moss collections from Jeju Island are described as new varieties. With the previous report of an

1 - Faculty of Biological Sciences, Chonbuk National University, Jeonju 561-756, Korea; e-mail: liebejun@jbnu.ac.kr

2 - The University and Jepson Herbaria, University of California, Berkeley, CA, USA 94720; e-mail: benctan@berkeley.edu 
endemic fern genus, Mankyua (Sun et al., 2001), and now the additional two new moss taxa, the isolated island of Jeju located at the southern end of the Korean Peninsula seems like a promising site to explore further for its little known cryptogamic plants, especially the bryophytes, in light of its established reputation as an important phytogeographical refugium and a local source of plant migration during the post glacial history of recolonization and plant speciation of the Korean Peninsula (Chung et al., 2013).

TAXA NEW TO SCIENCE

1. Fissidens involutus Wilson ex Mitt. var. jejuensis Y.-J. Yoon, B.C. Tan \& B.-Y. Sun, var. nov. [Fissidentaceae].

Fig. 1

Type: South Korea, on rock at Cheonjaeyeon waterfall, Jeju-do, 20 Mar 2012, Yoon Y.-J 10175 (holotype, JNU; isotypes, NY, UC).

Plants dark green. Stems sometimes branched, 2.5$3.5 \mathrm{~cm}$ long, 3-4 mm wide with leaves when wet, no differentiated central strand in cross-section; axillary hyaline nodules differentiated, consisting of a cluster of small thick-walled cells. Leaves as many as 25 pairs, somewhat imbricate, lanceolate-elongate to elongate-lingulate, $2.5-3.5 \mathrm{~mm}$ long, about $0.5 \mathrm{~mm}$ wide, broadly acute and apiculate, base of dorsal lamina mostly decurrent, a few wedge-shaped; costa percurrent; margins serrulate throughout; vaginant lamina $3 / 5-1 / 3$ of leaf length; lamina unistratose, cells small, quadrate to hexagonal, 5-6 $\mu \mathrm{m}$ in diameter, strongly mammillose, thin to moderately thick walled; cells of vaginant lamina larger, with indistinct papilla each at four cell corners. Setae lateral on short branch, 4-6 mm long. Capsules inclined, 1-1.5 $\mathrm{mm}$ long. Spores not seen.

Habitat: On humus rocks at waterfall.

Distribution: Endemic to South Korea and Japan.

Note. Fissidens involutus is a widespread species in E Asia and SE Asia (Li et al., 2001). It is better known in Asian publications by its synonym, F. plagiochiloides Besch. The new var. jejuensis is of medium plant size for the genus, measuring to $2.5-3.5 \mathrm{~cm}$ long and 3-4 mm wide with leaves when wet. It differs from the typical variety by (1) the stem cross-section without a central strand; (2) leaves narrowly lanceolate-elongate to lingulate, while those of the typical variety are ovate-lanceolate to oblong-lanceolate; (3) the bases of dorsal leaves are distinctly decurrent, while those of the typical variety are mostly rounded to cuneate; and (4) several cells of basal vaginant lamina have single indistinct papilla at each corner. The obscurely round to hexagonal and mammillose cells of apical and dorsal laminae of the new variety measure 5-6 $\mu \mathrm{m}$. The hyaline nodules on the stems and branches of the var. jejuensis are often seen differentiated as a group of small, thick-walled cells that are not enlarged. Like the typical variety, the new variety prefers also a wet habitat.

The illustration of the new Japanese species record of "Fissidens bushii" in Suzuki and Iwatsuki (2012, Fig. 24) fits well with the concept of our new variety. We confirmed the conspecific nature of these specimens after studying the duplicates of Kimura 826 and T. Suzuki 61200 (NICH) kindly provided by Dr. Tad. Suzuki. The descriptions and illustrations of Fissidens bushii (Cardot \& Thér.) Cardot \& Thér. from North America published by Crum \& Anderson (1981) and Pursell (2007) show a small plant of about 4-7 $\mathrm{mm}$ high, with ovate to oblong-lanceolate, but not elongate-lingulate leaves, and without a decurrent leaf base. The habitat of $F$. bushii in North America is reported to be mainly on soil and rock in mesic woodland and disturbed road banks.

Fissidens gedehensis M. Fleisch., a Malesian species now reported from Japan (Suzuki \& Iwatsuki, 2012), may be mistaken for this variety with similarly oblong to lingulate leaves, but the former is a smaller plant of about 8-12 $\mathrm{mm}$ long and with no hyaline nodules developed on the stem. The leaf cells of the vaginant lamina of $F$. gedehensis are smooth.

Fissidens teysmannianus Dozy \& Molk. (see Iwatsuki \& Mohamed, 1987) is another species with similar plant size and leaf shape, but it differs from the new variety of F. involutus in having non-decurrent leaf bases and the absence of hyaline nodules on the stem.

2. Leskeodon maibarae (Besch.) B-C. Ho \& L. Pokorny var. jejuensis Y.-J. Yoon, B.C. Tan \& B.-Y. Sun, var. nov. [Daltoniaceae].

Fig. 2.

Type: South Korea, Saryeonisup-gil, Jeju-do, 13 May 2012, Yoon Y.-J. 1060 (holotype, JNU; isotypes, NY, UC).

Plants mat-forming, stems, when wet, measuring to $20 \mathrm{~mm}$ long and 3-4 mm wide including the lateral leaves, occasionally branched. Lateral leaves mostly oblong-elliptic, dorsal leaves broadly ovate to ovate-lanceolate, all with apiculate apices; marginal leaf border entire, narrow, consisting of 1-2 rows of elongate cells, not reaching the apex; costa about $2 / 3$ of the leaf length; upper laminal cells quadrate to hexagonal, thin-walled, $8-16 \mu \mathrm{m}$ in width; lower laminal cells larger, shortly rectangular; all leaves with 2-3 rows of smaller marginal cells throughout. Perichaetial leaves and sporophytes not seen.

Habitats: On rocks along the shaded and wet road bank in valley.

Distribution: Endemic to Jeju Island of South Korea.

Note. In South Korea, only one species of Leskeodon, L. maibarae (Besch.) B.-C. Ho \& L. Pokorny, is known. The new variety differs from the typical variety in having many broadly ovate to ovate-lanceolate leaves (Plate 2a \& b) with smaller apical and upper laminal cells that are quadrate-hexagonal measuring $8-16 \mu \mathrm{m}$ in width. Also, there is a tendency to see a slight differentiation of 2-3 rows of smaller marginal cells in the upper part of the leaf near the apex (see Plate 2c). The upper laminal cells of the var. maibarae are homogeneous in appearance, measuring about $13-35 \mu \mathrm{m}$ in width.

Although L. maibarae is a variable species in East Asia, the new variety is rather distinctive in having broad- 

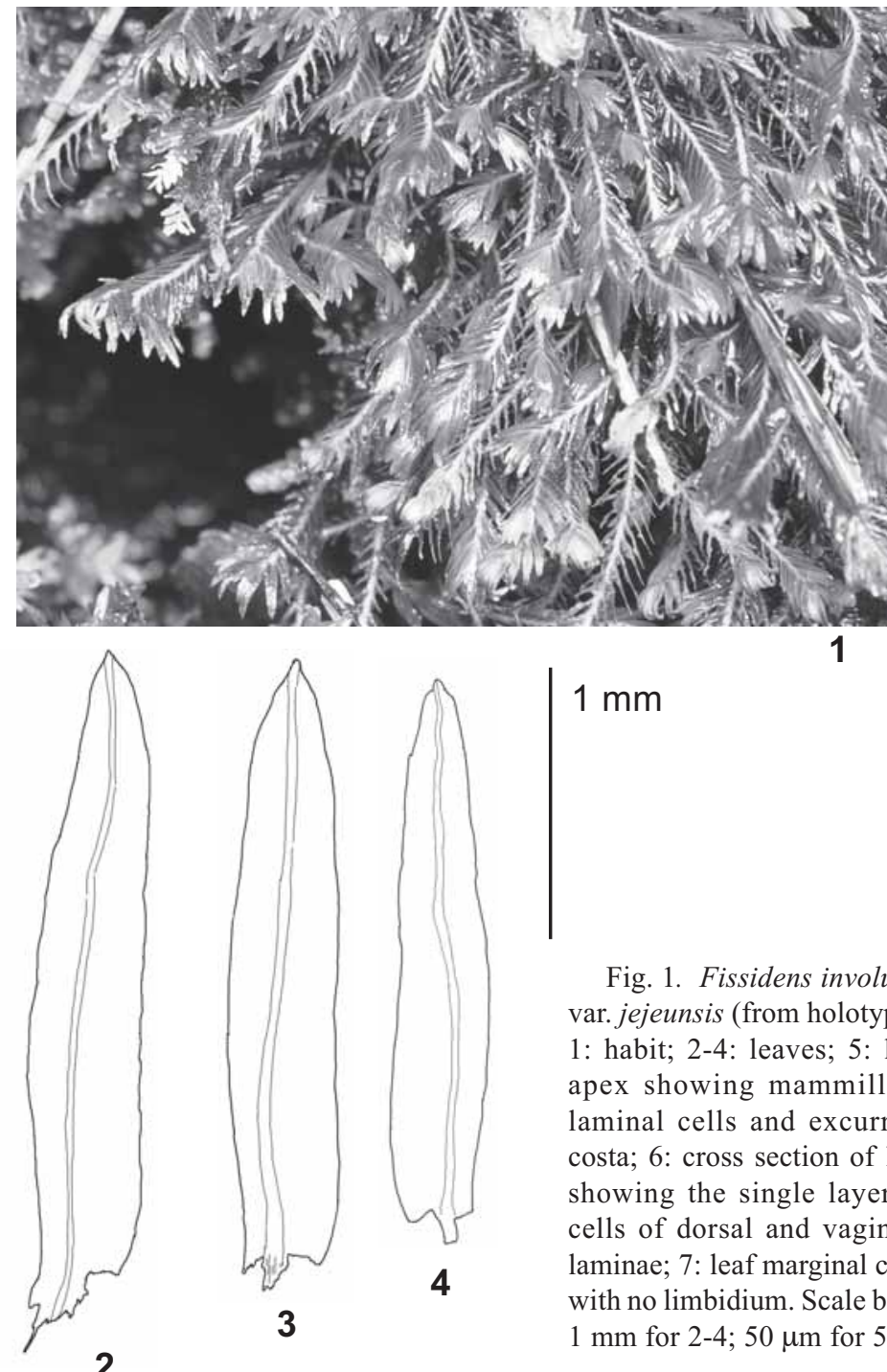

Fig. 1. Fissidens involutus var. jejeunsis (from holotype): 1: habit; 2-4: leaves; 5: leaf apex showing mammillose laminal cells and excurrent costa; 6 : cross section of leaf showing the single layer of cells of dorsal and vaginant laminae; 7: leaf marginal cells with no limbidium. Scale bars: $1 \mathrm{~mm}$ for $2-4 ; 50 \mu \mathrm{m}$ for 5-7.

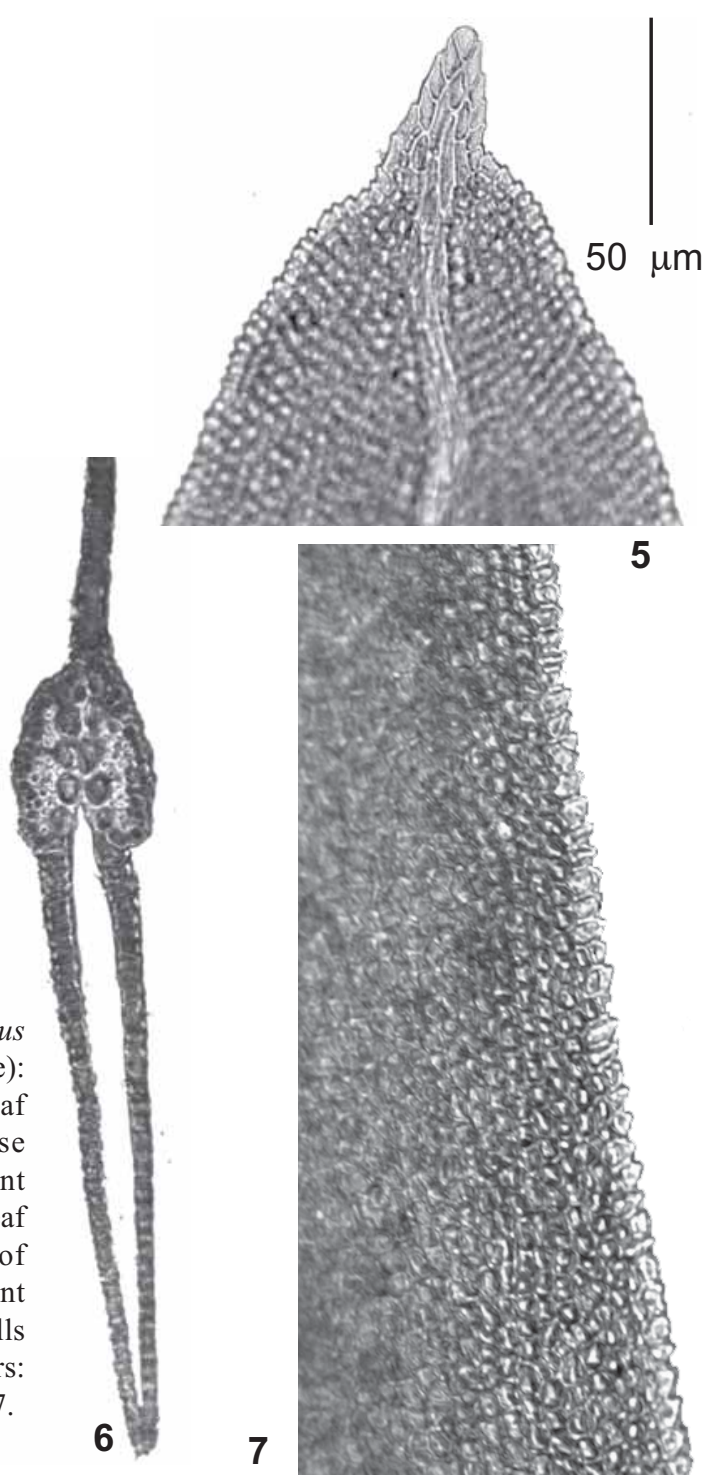

Note. Dicranum montanum is the smallest species of the genus in the Korean Peninsula. This species is similar in appearance to D. flagellare Hedw., but it can be distinguished by the following characters: (1) small plant size of 10-20 mm long; (2) strongly crisped leaves when dry; (3) upper laminal cells mammillose; and (4) without the flagelliform branchlets typically produced by plants of $D$. flagellare (Gao et al., 1999). Because of its somewhat erect capsule, the species has also been transferred to Orthodicranum as O. montanum (Hedw.) Loeske (Gao et al., 1999).

2. Fissidens anomalus Mont. [Fissidentaceae]

Specimen examined: South Korea, Hyodoncheon, Jeju-do, 7 Aug 2010, Yoon Y.-J 5488 (JNU).

Habitat: On shaded rocks.

Distribution: China, Nepal, India, Sri Lanka, Myanmar, Thailand, Vietnam, Indonesia and Philippines ( $\mathrm{Li}$ et al., 2001). New to the Korean Peninsula.

Note. The Fissidentaceae are the second-largest family in the moss flora of Korea, with 16 species of Fis- 


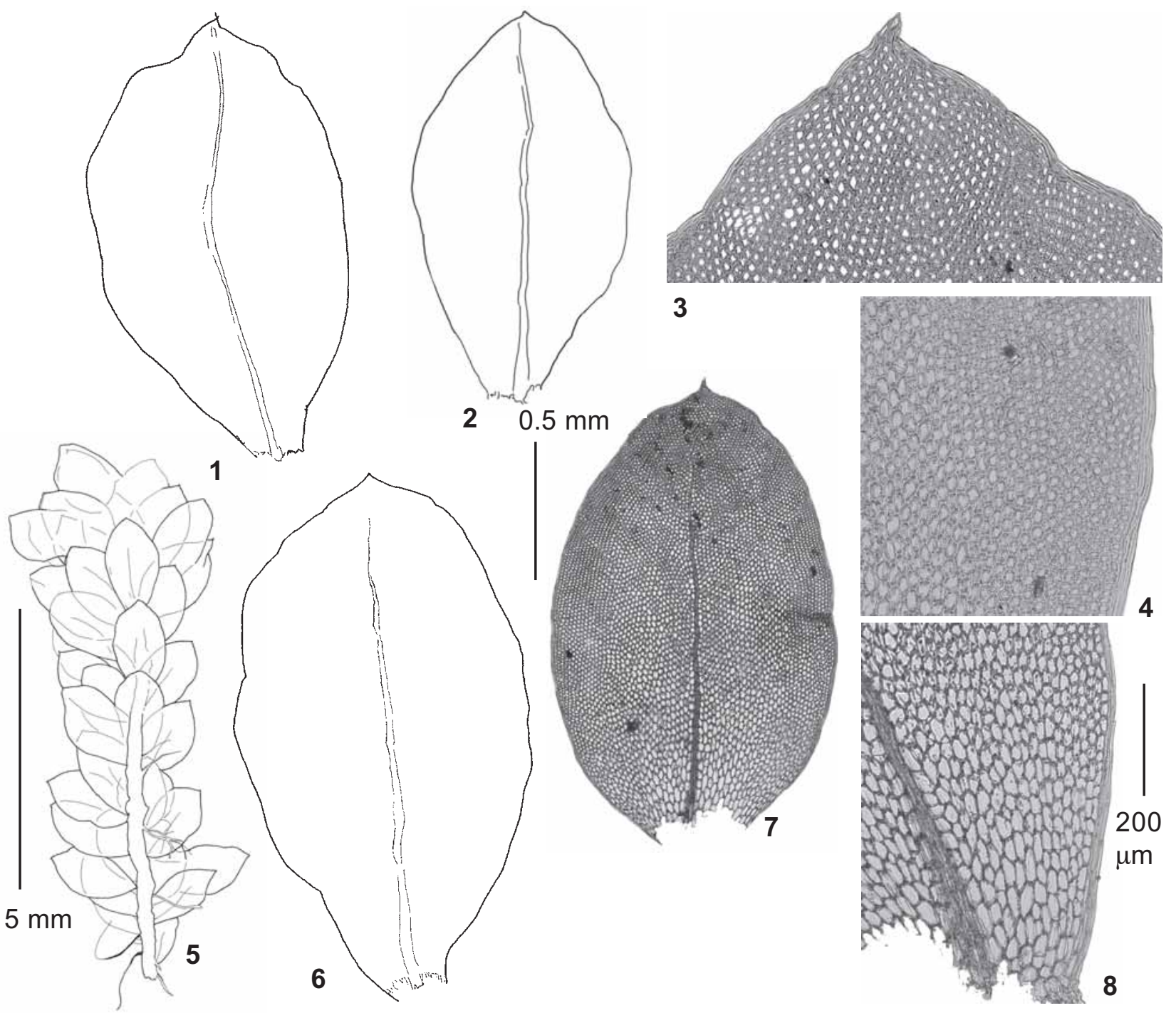

Fig. 2. Leskeodon maibarae var. jejeunsis: a \& b. lateral leaves; c. median leaf cells and the slightly smaller marginal cells near the narrow leaf border; d. leaf apex. Scale bars: $5 \mathrm{~mm}$ for $5 ; 0.5 \mathrm{~mm}$ for 1-2, 6; $200 \mu \mathrm{m}$ for 3-4, 8 .

sidens reported (Park \& Choi, 2007). The present species is similar to F. dubius P. Beauv. mainly in having 2-4 pale colored marginal rows of cells forming the irregularly serrate leaf border. However, it can be distinguished from the latter by its more narrowly lanceolate leaves with a more or less excurrent costa (Li et al., 2001).

Recently, F. bourgaeanus Besch., a neotropical species was found in Japan by Suzuki \& Iwatsuki (2012). The species looks like $F$. dubius and F. anomalus in having a differentiated marginal band of cells on the leaves, but in the former, this differentiated marginal band of leaf border cells is darker in color than the inner laminal cells, while the leaf marginal band of $F$. dubius and $F$. anomalous are lighter in color than the inner laminal cells. Considering the closeness of the Korean moss flora and Japanese moss flora, F. bourgaeanus is likely to be present in the Korean Peninsula.

3. Fissidens crispulus Brid. var. robinsonii (Broth.) Z. Iwats. \& Z.H. Li. [Fissidentaceae]
Specimen examined: South Korea, Seondol Valley, Jeju-do, 20 Jun 2011, Yoon Y.-J 7656 (JNU).

Habitat: On rocks along valley.

Distribution: China, India, Indochina, Malesia, New Caledonia. New to the Korean Peninsula.

Note. Fissidens robinsonii Broth. was reduced to a synonym of $F$. zippelianus Dozy \& Molk. (=F. crispulus) by Norris \& Koponen (1987), but was made a variety of F. zippelianus by Iwatsuki \& Suzuki (1989). The current recognition of this taxon by many muscologists is as a variety of F. crispulus, which is conspecific with F. zippelianus. The var. robinsonii differs from var. crispulus in having leaves with a narrowly acute apex and a slightly excurrent costa (Iwatsuki \& Suzuki, 1982, 1989).

4. Leskeodon maibarae (Besch.) B.-C. Ho \& L. Pokorny var. maibarae [Daltoniaceae]

Specimen examined: South Korea, Cheoreum Hammol-gu, Jeju-do, 19 Sept 2011, Yoon Y.-J 8411 (JNU). 
Habitat: On rocks.

Distribution: Japan, China, Taiwan, Philippines, India, Malaysia, Indo-China (Noguchi et al., 1991; Wu et al., 2002). New to the Korean Peninsula.

Note. This is a common and widespread species found in China and Japan. Its presence in the Korean Peninsula is expected. The species is well known in Asia by its former binomial, Distichophyllum maibare Besch. The recent transfer of the species to Leskeodon is supported by molecular studies of DNA sequences reported in Ho et al. (2012).

The species is best distinguished by having oblong to shortly spathulate lateral and dorsal leaves that have a narrow leaf border. The apiculate leaf apex consists of a few oblong cells that are different in shape from the elongate to linear border cells. The upper leaf cell are homogeneous, measuring about $13-35 \mu \mathrm{m}$ in width. Its habitat includes mainly wet rocks and soil, occasionally on decaying log in deeply shaded humid sites.

5. Okamuraea hakoniensis (Mitt.) Broth. fo. multiflagellifera (S. Okam.) Nog. [Brachytheciaceae]

Specimen examined: South Korea, Mt. Halla, Jejudo, 21 Sep 2011, Yoon Y.-J 8547 (JNU).

Habitat: On decayed wood.

Distribution: China and Japan (Wu et al., 2002). New to the Korean Peninsula.

Note. Okamuraea hakoniensis differs from its congeners in having non-plicate leaves with long or slenderly acuminate apices. The presence of many flagelliform branchlets covered with reddish brown fasciculate rhizoids distinguishes this form from the typical O. hakoniensis (Wu et al., 2002).

\section{Pylaisia selwynii Kindb. [Hypnaceae]}

Specimen examined: South Korea, Seonunsa, Gochang-gun, Jeollabuk-do, 6 Feb 2009, Yoon Y.-J 2222 (JNU).

Habitat: On base of tree.

Distribution: China, Japan, Russian Asia, North Europe, North America (Wu et al., 2005; Noguchi, 1994). New to the Korean Peninsula.

Note. This species is reported here new to the Korean Peninsula. The generic name, Pylaisia Schimp., is a conserved name against Pylaisiella Grout. The genus was revised recently by Arikawa (2004) who reported three species from the Korean Peninsula, namely, P. polyantha (Hedw.) Schimp., P. brotheri Besch. and P. stereodontoides Broth. Among its congeners in the Korean Peninsula, $P$. selwynii is closest to P. brotheri. The latter differs from $P$. selwynii in having (1) broadly ovate-lanceolate leaves with a gradually narrowed long-acuminate apex; (2) numerous alar cells (25-35); and (3) an ovoid capsule. $P$. selwynii has ovate-lanceolate leaves with somewhat constricted short-acuminate apices, about 20 25 alar cells along the leaf basal margin, and an ovoidoblong capsule. From P. polyantha, P. selwynii is distin- guished in having the endostome partly adhered to the exostome. The illustration of a free endostome in the peristomial structure of $P$. selwynii in Wu et al. (2005, Plate 209) is misleading. Pylaisia stereodontoides has lanceolate leaves with few alar cells and an oblong-elongate capsule (Arikawa, 2004; Wu et al., 2005).

7. Sematophyllum phoeniceum (Müll. Hal.) M. Fleisch. [Sematophyllaceae]

Specimen examined: South Korea, Daeheungsa, Haenam-gun, Jeollanam-do, 4 Feb 2009, Yoon Y.-J 2037 (JNU).

Habitat: On base of tree.

Distribution: China, India, Sri Lanka, Kampuchea, Laos, Vietnam, Africa (Tan \& Jia, 1999; Wu et al., 2005). New to the Korean Peninsula.

Note. This is the second species of the genus found in Korea after the report of S. subhumile (Müll. Hal.) M. Fleisch. (Park \& Choi, 2007). Its morphological differences from S. subhumile (Müll. Hal.) M. Fleisch. and S. subpinnatum (Brid.) Britt. are outlined in Tan and Jia (1999). Sematophyllum phoeniceum is best identified by its long acuminate and pointed leaf apices with elongate upper leaf cells (Tan \& Jia, 1999; Wu et al. 2005).

8. Sematophyllum subpinnatum (Brid.) E. Britton [Sematophyllaceae]

Specimen examined: South Korea, Bogil-do, Wando-gun, Jeollanam-do, 8 Mar 2011, Yoon Y. J 7002 (JNU).

Habitat: On rocks.

Distribution: Nearly pantropical, also in China, Japan, Russia Far East, Asia Minor, Europe (Noguchi, 1994; Wu et al., 2005). New to the Korean Peninsula.

Note. This is a new record and the third species of Sematophyllum found in Korea. Our species concept of this taxon includes $S$. caespitosum (Sw.) Mitt. and $S$. demissum (Wils.) Mitt. for its heterotypic synonyms. Sematophyllum subpinnatum can be identified from other congeneric species in Korean Peninsula by its leaves that are mostly ovate to broadly lanceolate with short-acuminate, acute to, at times, obtuse apices, and oval to rhomboidal upper leaf cells (see also Tan \& Jia, 1999; Wu et al., 2005).

\section{ACKNOWLEDGEMENTS}

We extend our best wishes to the honoree of this Festschrift issue of Arctoa, Dr. O.M. Afonina at Komarov Botanical Institute at St. Petersburg in Russia, on the occasion of her birthday in 2015 and in recognition of her great contributions to the Russian bryology over the decades. The work was supported by the grant "Survey of Korean indigenous Species (NIBR No. 2013-02-001)" from the National Institute of Biological Resources of Ministry of Environment in Korea. The third author (BCT) acknowledges also the technical assistance provided by his colleagues at UC Herbarium at Berkeley. Additionally, the positive re- 
viewing comments provided by W. Buck, H. Akiyama and J. Shevock are deeply appreciated. Dr. T. Suzuki is thanked for providing the alleged Japanese specimens of $F$. bushii for our study.

\section{LITERATURE CITED}

ARIKAWA, T. 2004. A taxonomic study of the genus Pylaisia (Hypnaceae, Musci). - J. Hattori Bot. Lab. 95: 71-154.

CARDOT, J. 1904. Premiere contribution a la flora bryologique de la Coree. - Beih. Bot. Centralbl. 17: 1-44.

CHOE, D. M. 1962. The value of affinities of Bryophytes among main mountains in South Korea, including Mt. Kyeryong. - M. Sc. Thesis, Kong Ju National University.

CHOE, D. M. 1972. Studies on the vegetation of Mt. Kyeryong, epiphytic bryological communities on rock. - J. Kongju Teacher's College 10: 265-269 (in Korean).

CHOE, D. M. 1977a. Studies on illustration of the Korean bryophyte, I. J. Kongju Teacher's College 15: 79-98 (in Korean).

CHOE, D. M. 1977b. Studies on illustration of the Korean bryophyte, II. - J. Kongju Teacher's College 15: 281-302 (in Korean).

CHOE, D. M. \& S. J. LEE. 1978. Studies on gemmae of the Korean mosses. Bryophyte. - J. Science Education 10: 77-86 (in Korean).

CHOE, D. M. 1979. The bryological flora and vegetation of Mt. Gyeryong and Mt. Chilgab area. - Report of Korean Association of Conservation of Nature 17: 91-104 (in Korean).

CHOE, D. M. 1980. Illustrated Flora and Fauna of Korea. Vol. 24. Musci-Hepaticae. - Ministry of Education, Seoul (in Korean).

CHUNG, M. Y., M.-O. MOON, J. LOPEZ-PUJOL, M. MAKI, T. YAMASHIRO, T. YUKAWA, N. SUGIURA, YUING-I LEE \& M. G. CHUNG. 2013. Was Jeju Island a glacial refugium for East Asian warmtemperate plants? Insights from the homosporous fern, Selliguea hastata (Polypodiaceae). -Amer. J. Bot. 100: 1-10.

CRUM, H. \& L. E. ANDERSON. 1981. Mosses of Eastern North America, volume 1. - Columbia University Press, New York: 1-663.

GANGULEE, H. 1977. Mosses of Eastern India and Adjacent Regions, fasc. 6. Hookeriales. - Calcutta: 1463-1546.

GAO, C. \& K. C. CHANG. 1983a. Bryophytes of North Korea. - Misc. Bryol. Lichenol. 9: 163-170.

GAO, C. \& K. C. CHANG. 1983b. Bryophytes of North Korea. - Bull. Bot. Res. 3: 118-131.

GAO C., M. R. CROSBY \& H. SI. 1999. Moss Flora of China, Volume 1. - Science Press and Missouri Botanical Garden Press, Beijing, New York \& St. Louis, $273 \mathrm{pp}$

HE, S. \& J.-S. SONG. 2007. New records of mosses from Ulleung Island, Korea. - J. Phytogeogr. Taxon. 55: 99-102.

HO, B.-C., L. POKORNY, B. C. TAN, J.-P. FRAHM, A. J. SHAW \& D. QUANDT. 2012. Molecular evolution and diversification of the moss family Daltoniaceae (Hookeriales, Bryophyta) with emphasis on the unravelling of the phylogeny of Distichophyllum and its allies. - Bot. J. Linn. Soc. 170: 157-175.

HONG, W.-S. 1960a. The bryophytes on Mt. Gwanak with some new additions to the Korean Flora. - Korean J. Bot. 3(2): 18-26.

HONG, W.-S. 1960b. The bryophytes on Mt. Soyo with some new addition to the Korean Flora. - Korean J. Bot. 3(1): 25-31.

HONG, W.-S \& H. ANDO. 1961. The flora of mosses on Mt. Chiri with some new addition to the Korean flora. - Korean J. Bot. 4(2): 41-52.

IWATSUKI, Z. \& M.A.H. MOHAMED. 1987. The genus Fissidens in
Peninsular Malaysia and Singapore (A Preliminary Study). - J. Hattori Bot. Lab. 62: 339-360.

IWATSUKI, Z. \& T. SUZUKI. 1982. A taxonomic revision of the Japanese species of Fissidens (Musci). - J. Hattori Bot. Lab. 51: 329-508.

IWASUKI, Z. \& T. SUZUKI. 1989. New Caledonian Fissidentaceae (Musci). - J. Hattori Bot. Lab. 67: 267-290.

KIM, Y.-H., Y.-R. RI, H.-D. HOANG, S. HUNECK \& R. GROLLE. 1995. Bryophytes and lichens of Mt. Kumgang (DPR of Korea.). - Feddes Repert. 106: 291-301.

LAI, M.-J., K. -W. PARK \& K. CHOI. 2007. New reports of bryophytes from Korea. - J. Nat. Taiwan Mus. 60: 63-66.

LI, X.-J, M. R. CROSBY \& H. SI. 2001. Moss Flora of China, Volume 2. - Science Press and Missouri Botanical Garden Press, Beijing, New York \& St. Louis, 283 pp.

NORRIS, D. H. \& T. KOPONEN. 1987. Bryophyte flora of the Huon Peninsula, Papua New Guinea. XX. Fissidentaceaea, Mitteniaceae, Phyllodrepaniaceae, Phyllogoniaceae and Sorapillaceae (Musci). - Ann. Bot. Fenn. 24: 177-219.

NOGUCHI, A., Z. IWATSUKI \& T. YAMAGUCHI. 1991. Illustrated Moss Flora of Japan. Vol. 4. - Hattori Botanical Laboratory, Nichinan: 743-1012.

NOGUCHI, A., Z. IWATSUKI \& T. YAMAGUCHI. 1994. Illustrated Moss Flora of Japan. Vol. 5. - Hattori Botanical Laboratory, Nichinan: 1013-1253.

PARK, K.-W. \& K. CHOI. 2007. New List of Bryophytes of Korea. Korea National Arboretum.

PURSELL, R.A. 2007. Fissidentaceae. - In: Flora of North America Editorial Committee. Flora of North America North of Mexico. Vol. 27. New York-Oxford: Oxford University Press: 331-357.

SCHOFIELD, W.B. 1985. Introduction to Bryology. - Macmillan Publishing Company, New York, 431 pp.

SONG, J.-S. \& K. YAMADA. 2001. A brief history of study of Hepaticae in Korean Peninsula. - Bryol. Res. 8(2): $42-44$ (in Japanese).

SONG, J.-S. \& K. YAMADA. 2003. A brief history of study of mosses in the Korean Peninsula. - Bryol. Res. 8(7): 219-222 (in Japanese).

SUN, B.-Y., H.-K. MOON, H.-K. CHUL \& C.-W. PARK. 2001. Mankyua (Ophioglossaceae): a new fern genus from Cheju Island, Korea. Taxon 50: 1019-1024.

SUZUKI, T. \& Z. IWATSUKI. 2012. Fissidens (Fissidentaceae, Bryopsida) species newly found in Japan. - Hattoria 3: 1-48.

TAN, B. C. \& Y. JIA. 1999. A preliminary revision of Chinese Sematophyllaceae. - J. Hattori Bot. Lab. 86: 1-70.

TAN, B. C. \& H. ROBINSON. 1990. A review of Philippine Hookeriaceous taxa (Musci). - Smithsonian Contr. Bot. 75: 1-41.

WU, P.-C., M.R. CROSBY \& H. SI. 2002. Hookeriaceae-Thuidiaceae. 6. - In: Moss flora of China. Science Press and Missouri Botanical Garden Press, Beijing, New York \& St. Louis, 221 pp.

WU. P.-C., M.R. CROSBY \& H. SI. 2005. Sematophyllaceae - Polytrichaceae. 8. - In: Moss Flora of China. Science Press and Missouri Botanical Garden Press, Beijing, New York \& St. Louis, 385 pp.

YOON, Y.-J., H.-K. CHUL, K.V. GOROBETS \& B.-Y. SUN. 2011 a. Unrecorded moss species from Korean flora II. - Korean J. Pl. Taxon. 41: $235-241$.

YOON, Y.-J., H.-K. CHUL, K.V. GOROBETS \& B.-Y. SUN. $2011 \mathrm{~b}$. The moss flora of Mt. Deogyu in Korea. - Korean J. Pl. Taxon. 41: 287-297.

YOON, Y.-J. \& B.-Y. SUN. 2010. Four unrecorded moss species from the Korean flora. - Korean J. Pl. Taxon. 40: 186-191. 